\title{
Prospective Reforms for Approximation of the Ukrainian Legal Framework for Telecommunications
}

\author{
Olga Batura $^{1}$ and Olga Kretova ${ }^{2}$ \\ ${ }^{1}$ Leuphana University of Lüneburg \\ ${ }^{2}$ Aalborg University \\ E-mail: batura@leuphana.de; oak@cmi.aau.dk \\ Received 22 May 2015; \\ Accepted 29 January 2016

\begin{abstract}
This article studies Ukrainian legal and regulatory rules for telecommunications services markets against the backdrop of Ukrainian commitments under the GATS and especially the Association Agreement with the EU. The study elucidates to what extent the Ukrainian telecoms regulatory framework complies with the relevant liberalisation and regulatory requirements and what prospective work on regulatory approximation still needs to be done.
\end{abstract}

Keywords: EU, Ukraine, trade in telecommunications services, liberalisation, regulatory approximation.

\section{Introduction}

This article studies the Ukrainian legal and regulatory framework for telecommunications services with the aim to understand its state-of-the-art and to identify the scope of reforms that have already been undertaken in order to

\footnotetext{
This article is based on the contribution prepared for the international conference "The Future of Cooperation between the European Union and Ukraine”, Kiel, 4 July 2014 and published by Centre of European Law and Politics, University Bremen, ZERP Working paper 1/2015 https://www.jura.uni-bremen.de/institutes/centre-of-european-law-and-politics/publications/ working-papers/

Journal of NBICT, Vol. 1, 19-38.

doi: 10.13052/NBICT.2016.002

(C) 2016 River Publishers. All rights reserved.
} 
liberalise the market and modernise the legislation. This will further allow rendering more precise the amount of improvements that still need to be done - against the backdrop of the Ukraine's commitments under the General Agreement on the Trade in Services (GATS) and the Association Agreement between the EU and Ukraine.

When in 2008 Ukraine became a member of the World Trade Organisation, it undertook commitments to liberalise, among other things, trade in services and to adopt a number of regulatory principles for the design of its domestic regulation. As of the $1^{\text {st }}$ of January 2016 when the Association Agreement between the EU and Ukraine entered into force, even more numerous and far reaching obligations of liberalisation and regulatory reform became binding on Ukraine. In both situations commitments with regard to the telecommunications services sector are quite prominent, which is easy to explain by the utmost important of the sector as indispensable for tradability of other services and many goods. Banking services, computer and audio-visual services, many professional and business services as well as ecommerce depend on information and communication technologies (ICT) and are delivered via telecommunications networks by using telecommunications services as carrier. Therefore, liberalisation of the telecommunications sector contributes directly to international trade in goods and services in general. Besides, telecommunications services are a valuable asset as such.

Due to particularities of trade in services, its liberalisation takes the form of "restricting domestic regulation" and always goes hand in hand with regulatory reforms. By contrast to trade in goods, barriers to trade in services do not consist of customs fees or import quotas, but are expressed in regulatory requirements. Liberalisation basically means to allow participation of the private sector in services provision, to allow foreign providers to compete with domestic providers, including state-owned undertakings, on a non-discriminatory basis and to eliminate other restrictions that encourage inefficient services provision (for instance, subsidies).

In order to set the scene for the Ukrainian legislation and reforms, this article will first provide a brief overview of Ukrainian commitments under the GATS and the Association Agreement with regard to the telecommunications sector. Next, against this backdrop, a snap-shot of the Ukrainian legal and regulatory framework on telecommunications sector will be presented in a comparative perspective in relation to the commitments. The main findings of the investigation with regard to this critical overview of the Ukrainian framework will be presented in the conclusion. 


\section{Ukrainian Commitments in the Telecommunications Sector under International Agreements}

In the telecommunications sector, Ukraine undertook far reaching commitments and agreed to liberalise both the so called basic and value-added telecommunications almost completely.

According to paragraph 1 of the Decision on Negotiations on Basic Telecommunications "basic telecommunications" are defined as "telecommunications transport of networks and services". ${ }^{1}$ Under the Services Sectoral Classification List, aka W120 list ${ }^{2}$, basic telecommunications are voice telephone services, packet-switched data transmission services, circuit-switched data transmission services, telex services, telegraph services, facsimile services, private leased circuit services. Due to the fact that the W120 list is an open one, Ukraine listed additional services as basic telecommunications: mobile voice and data services, paging services, teleconferencing services, integrated telecommunication services, excluding broadcasting. It is considered that value-added telecommunications meaning enhance the mere transportation of the electro-magnetic signal by processing, storing, forwarding or other operations with the signal without, however, changing the content of the transmitted message. In the Ukrainian schedule value-added services include electronic mail, voice mail, on-line information and data base retrieval, electronic data interchange, value-added facsimile services, including store and forward, store and retrieve, code and protocol conversion and on-line information services and/or data processing (including transaction processing).

In all the named types of telecommunications services, Ukraine shall provide market access and national treatment on the market with regard to cross-border supply ${ }^{3}$, consumption abroad ${ }^{4}$ and foreign commercial presence $^{5}$. Only with regard to the presence of natural persons ${ }^{6}$ no sector specific liberalisation is intended, which cannot be considered significant in case of

\footnotetext{
${ }^{1}$ Decision on Negotiations on Basic Telecommunications Services of 15 April 1994.

${ }^{2}$ MNG/GNS/W/120 of 10 July 1991.

${ }^{3}$ When both supplier and recipient stay in their respective States and only a service passes the frontier by means of (tele)communications.

${ }^{4}$ When a consumer crosses the border to receive a service.

${ }^{5}$ When a supplier from one state establishes a representation, a branch or other type of commercial presence in another state for purposes of services provision.

${ }^{6}$ When a service supplier from one state is only temporary established in the territory of another state by way of posting its workers or being present otherwise as a natural person (self-employed).
} 
telecommunications because the nature of telecommunications service is such that it does not require a personal (human) presence, but rather a commercial presence.

In relation to basic telecommunications only Ukraine also committed to comply with regulatory principles as contained in the Reference Paper on Regulatory Principles (Reference Paper) that are additional commitments to the GATS. This document addresses the most critical issues of telecommunications services sector and market in order to ensure effective opening up of national markets to foreign providers. In particular, in order to prevent anticompetitive practices by a major supplier, Ukraine is to adopt competitive safeguards against cross-subsidisation, using information from competitors with an anti-competitive intent and not providing competitors with technical information about essential facilities and with commercial information necessary for them to provide services. Ukraine has to provide that interconnection with a major supplier is ensured at any technically feasible point of the network under transparent and non-discriminatory conditions. Ukraine may introduce a universal service policy, but the respective obligations need to be administered in a transparent, non-discriminatory and competitively neutral manner and not to be more burdensome than necessary. The procedure of licensing as well as activities in the areas of rights of way, spectrum management and numbering shall be carried out in an objective, timely, transparent and non-discriminatory manner.

The Association Agreement is an enhancement of the commitments under the GATS. The main purpose of the Association Agreement is further (progressive) liberalisation of the market and regulatory approximation such that, with the time, no restrictions on services are left and the regulatory conditions are aligned sufficiently for Ukraine to participate in the internal market of the EU. As mentioned above, Ukrainian commitments in the telecommunications sector are already very far reaching such that very little can be promised in terms of market access (except for natural persons). Therefore, the Association Agreement emphasises regulatory approximation in the telecommunications sector that, if successful, shall be rewarded by granting telecommunications companies full freedom of establishment and freedom of services provision in the EU market as they are known under EU law. ${ }^{7}$

The specific obligations of regulatory approximation can be found in Subsection 5 Chapter IV and in Annex XVII of the Association Agreement.

\footnotetext{
${ }^{7}$ See, for instance, Barnard, Catherine, The Substantive Law of the EU: The Four Freedoms. Oxford: Oxford University Press, 2013.
} 
All the relevant provisions of the Association Agreement come straight from the EU's legal and regulatory framework for electronic communications, even with the same wording. In particular, the AA requires creation of an independent regulator for electronic communications that is legally distinct and functionally independent from any service provider. If state ownership of or control over a supplier of public communications networks or services is retained, effective structural separation of the regulatory function from activities associated with ownership or control shall be ensured. The AA aims at minimising red tape, specifically in the case of access to the market (via licensing). An authorisation for provision of electronic communications shall be in the form of mere notification and/or registration "as much as possible". Licences can be required for attribution of numbers and frequencies subject to a number of conditions ensuring a transparent, impartial and non-burdensome process of their issuance (Article 117 AA). Market regulation shall be closely aligned with the EU's framework. The market shall be primarily guided by competition law ${ }^{8}$, but where effective competition is lacking the independent regulator shall be able to intervene, to conduct a market analysis, to identify a provider with the significant market power and to impose obligations on it. The obligations to be imposed are designed to curb market power of the incumbent in order to create a level-playing field for competitors, especially for new entrants. The obligations are based on the EU experience in creation of the internal market for electronic communications and correspond fully to the obligations list in the EU Access Directive.

The Association Agreement also goes further in the requirements to spectrum management. It requires that assignment of radio frequencies is done in such a way that it optimises their use and facilitates the development of competition (Article 119 (2) AA). Regulation of the universal service provision is also more detailed and, additionally to the principles of efficiency, transparency, objectivity and non-discrimination, contains guidance on how to determine the net cost of universal service provision and whether it is an unfair burden on the designated supplier. There is also an indication of two financing mechanisms for universal service provision.

In order to ensure an effective regulatory approximation for the telecommunications sector, Annex XVII AA contains lists of legislative acts of the EU to be transposed into Ukrainian legislation. It follows that Ukraine is to transpose in its national law significant parts of five major Directives

\footnotetext{
${ }^{8}$ According to the provision of Chapter 10 Title IV AA, Ukrainian competition law will have to be significantly amended and will become similar to the EU competition law.
} 
regulating the internal market for electronic communications services: Framework Directive, Authorisation Directive (EPC 2002/20/EC), Access Directive (EPC, 2002/19/EC), Universal Service Directive (EPC, 2002/22/EC) and Competition Directive (EC, 2002/77/EC) - and the Decision on radio frequency policy in the EU (EPC, 676/2002/EC). This approach ensures that Ukraine effectively adopts EU's approach to regulation of telecommunications markets with a leading role of competition law and a corrective targeted intervention of a (strong) regulator to support or restore effective competition.

\section{Ukrainian Legal and Regulatory Framework for Telecommunications Sector}

This section examines the legal and regulatory framework governing the telecommunications sector of Ukraine, namely provision of telecommunications services and network infrastructure, with the aim to identify to what extent Ukraine has already reformed its legal and regulatory framework and what specific work is still necessary in order to comply with Ukrainian GATS commitments and the EU-Ukraine Association Agreement provisions. It starts with a brief overview of the main legislative acts regulating the telecommunications sector of Ukraine and explanations of some basic features of Ukrainian telecommunications Law. The current state of market liberalisation is analysed in terms of whether the market has in fact been liberalised and to what extent sector specific regulation is employed.

\subsection{Overview of the Legal Basis}

Key goals and strategies for the development of telecommunications networks for common use under market conditions and for attainment of strategic interests and competitiveness of Ukraine on the international market are defined in the Telecommunications Development Concept (CMU, 07.06.2006) adopted by the Cabinet of Ministers of Ukraine (CMU) in 2006. Within this policy framework, the main legislative acts regulating the provision of telecommunications networks and services in Ukraine are the Law of Ukraine "On Telecommunications" (Telecommunications Law) (VR, 2003), the Law of Ukraine "On Radio Frequency Resource of Ukraine" (Radio Frequency Law) (VR, 2000) and the Rules for Rendering and Obtaining of Telecommunications Services (Telecommunications Services Rules) (CMU, 11.04.2012). 
The Telecommunications Law sets out general objectives, principles and notions for the telecommunications market regulation as well as an institutional framework for regulation, governmental administration and operation of the telecommunications industry and telecommunications networks for common use. More specifically, it contains interconnection rules, licensing requirements and procedure, terms and conditions for the public telecommunications services provision, regulation of the numbering resource and tariff regulations.

Ukraine's telecommunications law operates under the principles of access to and availability of public (universal) telecommunications services of defined quality and range at an affordable price to all consumers in the entire territory of Ukraine, guarantees of interconnection and sustainability of the telecommunications networks, promotion of competition, efficient use and management of scarce resources, and efficiency and transparency of the telecommunications regulation (Article 6 of the Telecommunications Law).

Article 1 of the Telecommunications Law defines telecommunications as transmission, emission and/or reception of signs, signals, written text, images and sounds or messages of any kind by radio, wire, optical or other electromagnetic systems. Accordingly, a telecommunications service is a product of the activity of a telecommunications operator and/or provider aimed at satisfying consumer demands in the telecommunication area.

According to Article 38 of the Telecommunications Law, individuals and legal entities providing telecommunications services are divided into telecommunications service operators (telecom operators) and telecommunications service providers (telecom providers). The difference between the two is that telecom operators use, maintain and interconnect telecommunications networks, may obtain licences and numbering resource and assign it to endusers (secondary allocation), whereas telecom providers do not have these possibilities. In order to be able to provide telecommunications services, telecom providers have to enter into an agreement with a telecom operator who is an Ukrainian resident, and they further act on the basis of a telecommunications license of this operator covering the particular type of activity. Additionally, telecom providers have to enter their details into the Register of telecom operators and telecom providers (Register) (NCCIR, 2012), managed by the National Commission for the State Regulation of Communications and Informatisation (NCCIR).

Terms and conditions of telecommunications services provision are regulated in detail by various by-laws. For instance, the Telecommunications Services Rules aim at the protection of the rights of end-users of telecom 
services and govern the interaction between telecom operators and providers, on the one hand, and consumers of services, on the other.

The Radio Frequency Law establishes general rules for allocation and use of the radio frequency spectrum. It lays down competences of governmental bodies in regulating, controlling and monitoring the use of radio frequency spectrum and establishes liability for its misuse.

\subsection{Regulatory Authorities}

Pursuant to Article 13 of the Telecommunications Law, several governmental bodies are competent to regulate the telecommunications industry in Ukraine: the Cabinet of Ministers of Ukraine (CMU) (VR, 2014), the National Commission for State Regulation of Communications and Informatisation of Ukraine (NCCIR) (PU, 2011), the Ukrainian State Centre of Radio Frequencies (UCRF) (VR, 2000), the State Service of Special Communication and Information Protection in Ukraine (State Service) (VR, 2006), and others. It is, therefore, difficult to argue that Ukraine has one independent regulatory body as is presumably required by its international commitments.

The Cabinet of Ministers - the supreme body of executive power of Ukraine - is responsible for realisation of the state policy and state regulation of the telecommunications sector as a whole as well as operation and administration of the state-owned entities and facilities in the telecommunications domain (Article 14 of the Telecommunications Law). It directs and coordinates activities of other executive authorities in the telecommunications area, but also ensures protection of competition and equal market conditions for undertakings of all types of ownership.

The NCCIR acts as a principal regulator and develops the whole range of implementing instructions and regulations (Article 17 of the Telecommunications Law). The NCCR consists of the Chairman of the Commission and six Commission Members, who are appointed to and dismissed from their positions by the President of Ukraine. The NCCIR is structurally separate from the government, it is subordinated directly to the President of Ukraine and accountable to the Parliament of Ukraine - Verkhovna Rada. It is also legally distinct and functionally independent from any telecoms provider. The NCCIR comes close to being a sector regulator as required by international commitment. However, its complete independence is questionable because it is not formally established in the Telecommunications Law and because its members are appointed and dismissed by the President of Ukraine meaning that this can happen in an arbitrary manner. 
Yet, the NCCIR possesses the necessary competences that allow it to fully regulate, monitor and supervise activities in the telecommunications market. It allocates radio frequency spectrum and numbering resources to ensure their effective use; establishes licensing and registration procedures; sets tariffs for public telecommunication services, including special tariffs for socially disadvantaged, and controls quality of service; regulates interconnection and so on (Article 18 of the Telecommunications Law). The NCCIR can impose penalties on telecom operators and providers for violations of legal and regulatory provisions. Any decision by the NCCIR can be appealed to a court by an individual or a legal entity. These regulatory powers are sufficiently similar to the powers of national regulatory authorities under the Framework Directive of the EU.

More specifically, in accordance with "The procedure of market analysis of transmission services and identifying operators with significant market power" (NCCIR, 2011), the NCCIR conducts an analysis of the telecommunications market and prepares suggestions for legal acts and state regulation to ensure market balance, improvement of conditions for competition. The market analysis results in a NCCIR decision that identifies separate markets of telecommunications services and determines operators and/or providers with significant market power. This can further lead to imposition of specific obligations upon such operators and providers, for instance, application of special tariffs set by the NCCIR or obligation of interconnection with a telecommunications network of another operator at the points specified in the catalogue offers of telecommunications operators (Articles 18 and 59 of the Telecommunications law).

However, the NCCIR cannot impose any obligations on undertakings in order to control their anti-competitive behaviour under competition law. This competence is reserved for the national competition authority - the Antimonopoly Committee of Ukraine (VR, 1993). The NCCIR can only impose penalties when a telecommunications undertaking violates conditions of its license or does not comply with price regulation. To this end, the NCCIR lacks competences to regulate all aspects of the telecommunications market and to respond to non-competitive practices, which is again similar to the situation of national regulatory authorities in the EU. In the cases of breach of competition law and when there are reasoned suspicion or signs of abuse of dominant position on the telecoms market, the NCCIR hands over all materials of its analysis to the Antimonopoly Committee with the request to examine whether there is effective competition on the market (Article 18 of the Telecommunications Law). 
Its legal status does not allow the NCCIR to initiate legislative proposals or to submit draft laws, related to the regulation of the telecommunications sector, directly to the Parliament of Ukraine. However, in accordance with Article 18 of the Telecommunications Law and paragraphs 4.4 and 4.5 of the Regulation of the NCCIR, the NCCIR can make suggestions for legislative proposals and standards in the spheres of its competences to the President and the Cabinet of the Ministers of Ukraine.

The NCCIR exercises its activities in compliance with the principle of openness (Article 22 of the Telecommunications Law). Comprehensive information about the NCCIR, its activities and adopted documents is publicly available in official publications and via the NCCIR's website ${ }^{9}$. The NCCIR establishes conditions to organise public participation at its meetings and consultations for decision-making processes. One of the common practices in this regard is organisation of round tables to enhance an interaction between the NCCIR and public.

Under Article 11 of the Radio Frequency Law, the Ukrainian State Centre of Radio Frequencies is the central executive body to carry out administration and control over the radio spectrum resources of Ukraine. The UCRF is obliged to ensure the effective use of the radio frequencies and to this end it is entrusted with the tasks of allocation and use of the radio frequency spectrum. In its activity the UCRF is subordinated to and supervised by the NCCIR (Article 14 of the Radio Frequency Law).

The State Service is another central executive body in the telecommunications sector that is largely responsible for standard-setting, establishment of precise requirements for networks, services and equipment, and for their control and certification. Besides, it develops and implements state technical policy in the field of cryptographic and technical information security, telecommunications, and radio frequency resource of Ukraine (Article 14 of the Law of Ukraine "On the State Service for Special Communications and Information Protection of Ukraine").

\subsection{Providing Telecommunications Services in Ukraine}

Article 6 of the Telecommunications Law reserves the exclusive right to provide telecommunications services for Ukrainian entities. Legal entities shall be located in the Ukrainian territory and incorporated in accordance with Ukrainian laws, and natural persons who are business entities shall have

\footnotetext{
${ }^{9}$ See http://nkrzi.gov.ua.
} 
permanent residence in the territory of Ukraine. At the same time, Ukraine is open to foreign equity ownership and has no restrictions on foreign direct or indirect ownership of companies or investment in telecoms sector. This means that market access and market activity for foreign operators is strongly restricted at the moment, and trade is possible only by the way of cross-border supply and consumption abroad. Trade in services via commercial presence of foreign operators will be the next step: according to the Association Agreement between the EU and Ukraine full freedom or services provision and freedom of establishment should be granted upon successful regulatory approximation in the sector.

\subsubsection{Licensing}

Licensing is a key tool of telecommunications regulation to control market entry and, therefore, can be used to shape the market by limiting the number of players and/or types of services provided.

In the legal framework of Ukraine general authorisation regime in form of notification, similar to the one required by the EU framework, had been applicable until the Market Access Law was adopted in 2011 (VR, 2011). The latter introduced a regime of individual authorisation. An undertaking may operate on the telecommunications market of Ukraine upon the simple entering into the Register, if the intended activities can be carried out without a license. In such a case, an undertaking must comply with the Telecommunications Services Rules. Business entities, intending to engage in licensed activities, must submit an application for entry into the Register and an application for license to the NCCIR accompanied by a number of documents.

An exhaustive list of telecommunications services subject to licensing is contained in Article 42 of the Telecommunication Law. Basically, only the activities of telecom operators, not providers are listed there: local, inter-city and international fixed-line telephone services, with the right to maintain and operate telecommunications networks and lease communications channels; local, inter-city and international fixed-line telephone services using wireless access to telecommunications networks, with the right to maintain and operate telecommunications networks and lease communications channels, mobile services, with the right to maintain and operate telecommunications networks and lease communications channels; maintenance and operation of a telecommunications network, on-air and cable broadcasting and television networks. This makes it overall more complicated to operate within the Ukrainian market as a telecom operator than as a telecom provider. Even though licensing is admissible under the GATS and Association Agreement, 
the range of licensing obligations in Ukraine is unusually large, especially by comparison with the EU where licences are only employed to allocate radio frequencies.

According to Article 47 of the Telecommunications Law, the NCCIR may take a decision on restricting the quantity of licenses for certain kinds of business activity in the area of telecommunications services provision in order to ensure the efficient use of telecom networks and scarce resources in the interest of consumers. Although in these circumstances licensing is used to control market entry, the Article provisions are constructed to introduce competition. Thereby, if a decision on restricting the quantity of licenses is made, the licenses shall be granted on a competitive basis in an open, nondiscriminatory and transparent procedure (a tender) and under equal conditions and requirements for all participants, which means individual requirements cannot be included to the license terms. These conditions are in line with the requirements of the GATS and Association Agreement.

In accordance with Article 48 of the Telecommunications Law, the validity term of telecommunications licenses is determined by the NCCIR individually, but may not be less than 5 years.

The Cabinet of Ministers of Ukraine determines a fee for the issuance of licenses, reissuance thereof, issuance of duplicates, copies and extension of the period of validity. The amount of a fee varies strongly depending on the telecommunication service from UAH 340 for provision of fixed-line telephone services in rural areas to UAH $8933000^{10}$ for provision of international fixed-line telephone services (Article 53 of the Telecommunications Law). As a result, even when the number of licenses to provide services in a particular market is not formally limited, it is apparent that high license fees can effectively limit the number of entrants to a lucrative market that is being reserved for the incumbent.

\subsubsection{Scarce telecommunications resources}

Both radio frequencies and numbering resources are recognised by the Telecommunications Law as scarce resources (Article 70 of the Telecommunications Law). In order to ensure that they are utilised efficiently and managed in the best interest of society the Telecommunications Law establishes principles of their allocation: openness, non-discrimination, impartiality, competitiveness and equality of rights of access to the scarce resources for all telecommunications operators, usage of the numbering resource on a

\footnotetext{
${ }^{10}$ In January 20161 euro was equal to approximately 27 UAH.
} 
permissive and paid basis ensuring the rational use of the numbering resource (Article 69 of the Telecommunications Law in conjunction with Article 30 of the Radio Frequency Law).

Radio frequency spectrum allocation is carried out according to the Plan for the Use of Radio Frequency Resource in Ukraine (Radio Frequency Plan) (CMU, 09.06.2006) (Article 23 of the Radio Frequency Law). The Radio Frequency Plan is designed to ensure a forward-looking implementation of radio technologies and efficient use of radio frequency resources in Ukraine. It provides an exhaustive list of permitted radio technologies with the definition of radio frequencies and radio communication services, and termination terms of use.

The radio frequency spectrum may be allocated on a competitive basis through tender or auction procedure or on a non-competitive basis. In case the demand for the radio spectrum exceeds its availability, the license is granted on a competitive basis according to procedures and conditions established by the NCCIR. The announcement of a tender and the results of such tender shall be published in the NCCIR official bulletin. This manner of allocation corresponds to the international practice and is in compliance with both the GATS and the Association Agreement.

Licensing is a common procedure of frequencies allocation. Pursuant to the Radio Frequency Law (Article 29, 31), the following activities are subject to individual authorization, and the legislation provides no exemptions under which such requirement can be waived: use of radio frequencies for telecommunication activities (license for use of radio frequencies) and use of radio, electronic and/or transmitting devices.

Fees for the issuance of a license for the use of radio frequency resource of Ukraine for a period of five years depend on the geographical location of the area where services shall be provided, the frequency range and vary from a minimum fee of UAH 170 to a maximum fee of UAH 1360000 (in Kiev) per $1 \mathrm{MHz}$ (CMU, 22.02.2006). The license is granted to a particular legal entity and cannot be transferred.

If the licensing activity requires the use of numbering resources, a telecom operator must obtain the permit for allocation of the numbering resource from the NCCIR (Article 70 of the Telecommunications Law), which is not a common practice, for instance, in the EU. For allocation of numbering resources, the telecom operator shall file a respective application to the NCCIR with necessary supporting documents (letter of substantiation, business plan, etc.). The permit specifies the validity period of the respective telecommunications license without the right to assign it to third parties, except for secondary 
allocation to end-users. The permit and the allocated numbering resource can be withdrawn on the basis of the NCCIR decision in the case of a misuse of the numbering resource or its illegal transfer to third parties, in case of an annulment or expiry of the license that was a ground for allocation of the numbering resource, and if the telecom operator applies for this (Article 70 of the Telecommunications Law).

\subsubsection{Interconnection}

The regulatory authority is obliged to ensure smooth interconnection between operators, including national roaming and the possibility of migration of phone numbers between operators, their cooperation for interconnection purposes, based on an individual agreement between two market players. It also resolves disputes with regard to the interconnection between telecommunications networks. These competences of the regulator are in line with the GATS and Association Agreement and correspond to the requirements of the EU framework.

Article 57 of the Telecommunications Law lays down principles of interconnection between networks and contains relevant requirements to operators. Technical, organizational, commercial conditions and tariffs of interconnection to the operators that hold the monopolistic (dominant) position in the telecommunications market shall be regulated by the NCCIR. Telecommunications operators are obliged to comply with technical requirements and the traffic routing procedure stipulated for telecommunications networks. The decision of the NCCIR on the issues that arise between operators when entering into a contract on interconnection is binding and can be revoked only upon the court decision.

Article 60 of the Telecommunications Law and the Rules on interconnection of telecommunications networks contain the main requirements of mainly procedural nature to agreements on network-to-network interconnection (NCCIR, 2005). All telecom operators and telecom providers shall notify the NCCIR when they enter into interconnection agreements, amend or terminate them. However, there is no obligation to disclose executed contracts (Article 60 of the Telecommunications Law).

The Telecommunications Law foresees special obligations for the telecom operator with significant market power as required both by the GATS and Association Agreement. Such operator has no right to reject requests for interconnection with its telecommunications network unless a network to be interconnected with does not meet the requirements set out in the Telecommunications Law (Article 60 of the Telecommunications Law). The NCCIR 
publishes information on interconnection agreements concluded by telecom operators on a quarterly basis (Art 59 of the Telecommunications Law).

\subsubsection{Protection of public interest and consumer rights}

Article 62 of the Telecommunications Law introduces the notion of publicly available telecommunications services; this implies a minimum set of services of standardised quality defined by this Law that is accessible to all consumers in the entire territory of Ukraine. Ukraine aims for ubiquitous coverage of its territory with publicly available services as the Concept of Telecommunications Development of Ukraine suggests (CMU, 07.06.2006). The Concept foresees a procedure and terms for providing access to publicly available services for consumers in rural, mountainous areas, as well as vulnerable consumer groups such as families with low income, pensioners and disabled people and foresees deadlines for providing the possibility of general access to publicly available services to the whole population of Ukraine, physical construction volumes of telecommunications networks and necessary capital investments for achieving this objective.

Telecommunications operators and providers are obliged to employ special tariffs for publicly available telecommunications services to disabled and socially vulnerable persons - to be financed from a compensation mechanism to be set up by the Cabinet of Ministers of Ukraine. Emergency services (calling the fire brigade, police, ambulance, gas emergency service) shall be provided free of charge (Article 39 of the Telecommunications Law).

According to universal access provisions, when consumer demand for publicly available telecommunications services is insufficiently satisfied in certain regions of Ukraine, the NCCIR can take a decision to impose an obligation to develop and provide publicly available telecommunications services to consumers on the telecommunications operators with dominant position in that market. For the loss occurred while fulfilling these obligations, compensation may be requested through the mentioned compensation mechanism.

The concept of universal service in Ukraine largely corresponds to the requirements of the GATS and Association agreement. However, the compensation mechanism and the amount of compensation as well as the procedure of designation of a universal service operator are not quite up to the standards because they do not ensure a completely objective non-discriminatory treatment of operators and distort the level playing field. 


\section{Perspectives of Regulatory Approximation}

The examination of the Ukrainian legislation and regulation governing telecommunications sector against the backdrop of its international obligations demonstrates that Ukraine has utilized the accession guideline and negotiation procedure to the WTO in order to substantially revise its legal basis, to partially liberalise access to its domestic services market and to lower some of regulatory barriers. At the moment, the majority of Ukrainian's commitments under the GATS and the Association Agreement are on the way to be realised as the legal foundation for it is in place.

Although Ukraine has arguably started a comprehensive reform to modernise its legislation and transform its telecommunications market, the complex requirements under the Association Agreement, especially those with regard to regulatory approximation, are not likely to be reached in the near future. To start with, the independence and competences of the regulator NCCIR need to be further enhanced, especially in the sphere of regulation of operators and providers with significant market power. The role of the NCCIR in market regulation needs to be upgraded with the aim to make it less intrusive and more appropriate for the time of transition from monopoly to competitive market. For this, the regulatory capacity of the NCCIR in defining markets susceptible to regulation needs to be enhanced, the list of possible remedies shall be updated and the measures themselves to become more nuanced.

Principles of competition shall be deeper integrated in the sector specific regulation. For instance, the licensing regime should be reformed in order to further reduce the number of licences and to move in the direction of general authorisation as is the case under the EU framework. Price regulation shall become more cost oriented. In order to promote services competition, access obligations can be enhanced up to unbundling. The power of the incumbent, which is of particular concern, can be stronger controlled by introducing the possibility of accounting separation. This is in particular important considering the vertical integration of the incumbent: it owns the only fixed nation-wide infrastructure and also provides services to end-users, including universal service.

In the latter context also the rules on the universal service provision shall be made more competition-neutral by transposing the EU Universal Service Directive. A competitive selection procedure of designated undertaking can be introduced together with the possibility to designate different undertakings for different (small) geographic areas. Mechanisms of costing and financing need to be reviewed in order to prevent overcompensation and cross-subsidisation 
of the designated provider and to ensure that it does not get unfair competitive advantages.

Proper transposition of precisely defined EU law provisions and the development of correct implementation practices, as required by the Association Agreement, will take a lot of time and conceptual adjustment and may significantly exceed the four years deadline foreseen by the Association Agreement. The level of development of Ukrainian telecommunications infrastructure and institutional capacity lag behind EU Member States so that not all regulatory solutions required by the EU can be implemented in Ukraine and some intermediary steps will be necessary. Of significant importance for the success of regulatory approximation is an administrative reform, including reduction of corruption, which can and is supported by twinning programmes and cooperation between the EU's and Ukrainian regulators within the Electronic Communications Regulatory Platform EaPeReg ${ }^{11}$.

\section{References}

[1] European Parliament and the Council (EPC), 2002/22/EC. (2002a). Directive 2002/22/EC on universal service and users' rights relating to electronic communications networks and services, OJ L 108 of 24.04.2002. Available at: http://eur-lex.europa.eu/legal-content/EN/ALL /?uri=CELEX\%3A32002L0022

[2] European Parliament and the Council (EPC), 2002/19/EC. (2002b). Directive 2002/19/EC on Access To, And Interconnection Of, Electronic Communications Network And Associated Facilities, OJ L 108 of 24.04.2002. Available at: http://eur-lex.europa.eu/legal-content/EN/ ALL/?uri=CELEX\%3A32002L0019

[3] European Parliament and the Council (EPC), 2002/20/EC. (2002c). Directive 2002/20/EC on the authorisation of electronic communications networks and services, OJ L 108 of 24.04.2002. Available at: http://eurlex.europa.eu/legal-content/EN/TXT/PDF/?uri=CELEX:32002L0020\& from $=\mathrm{EN}$

[4] European Parliament and the Council (EPC), 676/2002/EC. (2002c). Decision 676/2002/EC of 7 March 2002 on a regulatory framework for radio spectrum policy in the European Community, OJ L 108 of 24.04.2002. Available at: http://eur-lex.europa.eu/legal-content/EN/ TXT/PDF/?uri=CELEX:32002D0676\&rid=5

\footnotetext{
${ }^{11}$ See http://www.eapereg.eu/
} 
[5] European Commission (EC), 2002/77/EC. (2002d). Directive 2002/77/ EC of 16 September 2002 on competition in the markets for electronic communications networks and services, OJ L 249 of 17.09.2002. Available at: http://eur-lex.europa.eu/legal-content/EN/TXT/PDF/?uri=CELE $\mathrm{X}: 32002 \mathrm{~L} 0077 \&$ from $=\mathrm{GA}$

[6] Parliament of Ukraine Verkhovna Rada (VR). (2003). Закон України “Про телекомунікаціï”, kyiv, 18 November 2003, N 1280-IV. Available at: http://zakon4.rada.gov.ua/laws/show/1280-15

[7] Parliament of Ukraine Verkhovna Rada (VR). (2000). Закон України, “Про радіочастотний ресурс України”, Kyiv, 1 June, 2000, N 1770-III. Available at: http://zakon3.rada.gov.ua/laws/show/1770-14

[8] Parliament of Ukraine Verkhovna Rada (VR). (2014). Закон України “Про Кабінет Міністрів України”, Kyiv, 27 February 2014, N794 - VII. Available at: http://zakon2.rada.gov.ua/laws/show/2591-17

[9] Parliament of Ukraine Verkhovna Rada (VR). (2006). Закон України "Про Державну службу спеціального зв' язку та захисту інформації України”, Kyiv, 23 February 2006, N3475-IV. Available at: http://zakon4.rada.gov. ua/laws/show/3475-15

[10] Parliament of Ukraine Verkhovna Rada (VR). (1993). Закон України “Про Антимонопольний комітет України", Kyiv, 26 November 1993, N3659 - XII. Available at: http://zakon2.rada.gov.ua/laws/show/3659-12

[11] Parliament of Ukraine Verkhovna Rada (VR). (2011). Закон України “Про внесення змін до деяких законів України щодо спрощення умов доступу на ринок телекомунікаційних послуг”. Kyiv, 5 July 2011, N 3566-VI. Available at: http://zakon4.rada.gov.ua/laws/show/3566-17

[12] President of Ukraine (PU). (2011). Указ Президента України “Про Національну комісію що здійснює державне регулювання у сфері зв'язку та інформатизації”. Kyiv, 23 November 2011, N 1067/2011. Available at: http://zakon2.rada.gov.ua/laws/show/1067/2011

[13] Cabinet of Ministers of Ukraine (CMU). (2012). Постанова Кабінету Міністрів України “Про затвердження Правіл надання та отримання телекомунікаційних послуг”, Kyiv, 11 April, 2012, N 295. Available at: http://zakon4.rada.gov.ua/laws/show/295-2012-п

[14] Cabinet of Ministers of Ukraine (CMU). (2006a). План використання радіочастотного ресурсу України. Kуiv, 9 June 2006, N 815. Available at: http://zakon4.rada.gov.ua/laws/show/815-2006-п

[15] Cabinet of Ministers of Ukraine (CMU). (2006b). Постанова Кабінету Міністрів Украіни “Про розміри плати за видачу, продовження строку дії, переоформлення, видачу дублікатів ліцензій на користування 
радіочастотним ресурсом України". Kyev, 22 February 2006, N 200. Available at: http://zakon1.rada.gov.ua/laws/show/200-2006-п

[16] Cabinet of Ministers of Ukraine (CMU). (2006c). Конценція розвитку телекомунікацій в Україні, 7 June 2006, N 316-p. Available at: http:// zakon4.rada.gov.ua/laws/show/316-2006-p

[17] National Commission for State Regulation of Communications and Informatisation of Ukraine (NCCIR). (2011). Рішення Національної комісії 3 питань регулювання зв'язку України “Порядок аналізу ринків послуг пропуску трафіка та визначення операторів телекомунікацій $з$ істотною ринковою первагою" Kiyv, 25 August 2011, N444. Available at: http:// zakon4.rada.gov.ua/laws/show/z1078-11

[18] National Commission for State Regulation of Communications and Informatisation of Ukraine (NCCIR). (2012). Порядок ведення реєстру операторів провайдерів телекомунікацій. Approved by the Decision of the NCCIR, Kyiv, 1 November 2012, N 560. Available at: http:// zakon4.rada.gov.ua/laws/show/z0032-11

[19] National Commission for State Regulation of Communications and Informatisation of Ukraine (NCCIR). (2005). Правила взаємоз'єднання телекомунікаційних мереж загального користування. Kyiv, 8 December 2005, N 155. Available at: http://zakon4.rada.gov.ua/laws/show/z0071-06

\section{Biographies}

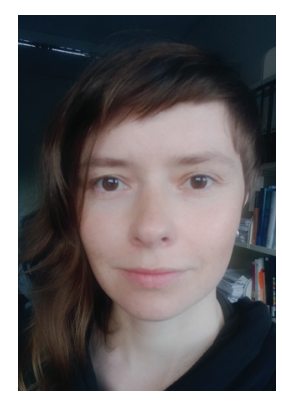

O. Batura is an associate professor at the European Humanities University in Vilnius, Lithuania, and a researcher at the Leuphana University in Lüneburg, Germany. Her research focuses on EU and international law, in particular on international trade in telecommunications services and regulation of electronic communications markets. Olga Batura holds master degrees from the University of Bremen and from the Europa Kolleg of the University of Hamburg. 
In 2013 she defended her doctoral dissertation on the regulation of universal service in the EU and WTO legal frameworks at the University of Bremen.

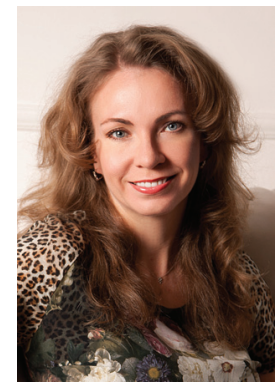

O. Kretova is a $\mathrm{PhD}$ fellow at Aalborg University and holds a master degree in law. She is an experienced lawyer, specialising in IT and telecommunications law as well as in other more general legal subjects. The topic of her research is legal and political barriers and challenges the telecoms business operators face while deploying telecoms solutions in Ukraine. Apart from studying telecommunications regulation, as part of interdisciplinary research she also analyses technical and infrastructural conditions of the telecommunications sector in Ukraine to define the gap in technology and visualise the technical feasibility for deploying of the modern telecoms solution.

As an external expert in the Kyiv Smart City initiative she is working on the projects concerned with public e-services development, cybersecurity and personal data protection. 